\title{
THE VEGETATION OF THE ISLET OF BADIJA (SOUTH CROATIA), WITH SOME NOTES ON ITS FLORA
}

\author{
Nenad Jasprica ${ }^{1} \&$ Milenko Milović ${ }^{2}$ \\ ${ }^{1}$ Institute for Marine and Coastal Research, University of Dubrovnik, P.O. Box 83, \\ HR-20000 Dubrovnik, Croatia (e-mail: nenad.jasprica@unidu.hr) \\ ${ }^{2}$ Antun Vrančić Grammar School, Put Gimnazije 64, HR-22000 Šibenik, Croatia
}

\begin{abstract}
Jasprica, N. \& Milović, M., The vegetation of the islet of Badija (south Croatia), with some notes on its flora. Nat. Croat., Vol. 25, No. 1, 1-24, 2016, Zagreb.

The vegetation and flora of the south Croatian islet of Badija $\left(0.97 \mathrm{~km}^{2}\right)$, located in the Korčula archipelago, were studied in 2014 and 2015. From a total of 52 phytosociological relevés, 12 floristically and ecologically distinctive vegetation communities were identified and described (eight associations, one subassociation and three stands) within nine vegetation classes. Among them, Teucrio capitatiMarrubietum incani Jasprica et Milović 2016 is described and proposed as a new association, belonging to the Stellarietea mediae class. Altogether, nine NATURA 2000 habitat types were recognized. Regarding the flora, 27 new vascular plant taxa (26 species and one subspecies) were recorded for the islet. Therefore the entire recorded flora of the islet of Badija now consists of 409 vascular plant taxa. Of the newly recorded taxa, four are considered to be invasive. One taxon is strictly protected by law. The Red List categories Least Concern (LC) and Data Deficient (DD) are assigned to one species in each.
\end{abstract}

Key words: phytosociology, new syntaxon, vascular plants, new records, Directive 92/43/EEC, eastern Adriatic, Mediterranean

Jasprica, N. \& Milović, M., Vegetacija na otočiću Badiji (južna Hrvatska) s florističkim bilješkama. Nat.Croat., Vol. 25, No. 1, 1-24, 2016, Zagreb.

Vegetacija i flora južnojadranskog otočića Badije $\left(0,97 \mathrm{~km}^{2}\right)$, smještenog u korčulanskom arhipelagu, istraživani su 2014. i 2015. Na temelju 52 fitocenološke snimke određeno je i opisano 12 floristički i ekološki različitih vegetacijskih zajednica (osam asocijacija, jedna subasocijacija i tri sastojine) u okviru devet vegetacijskih razreda. Među njima, asocijacija Teucrio capitati-Marrubietum incani Jasprica et Milović 2016 opisana je i predložena kao nova za znanost, a pripada vegetacijskom razredu Stellarietea mediae. Uvtrđeno je devet NATURA 2000 stanišnih tipova. Determinirano je 27 novih svojti (26 vrste i jedna podvrsta) vaskularnih biljaka za otočić, pa je ukupan broj svojti sada 409. Među novim svojtama, četiri su invazivne, jedna je zakonski strogo zaštićena. Po jedna svojta pripada kategorijama najmanje zabrinjavajućih (LC) i nedovoljno poznatim biljkama (DD).

Ključne riječi: fitocenologija, novi sintakson, vaskularne biljke, novi nalazi, Direktiva 92/43/EEZ, istočni Jadran, Sredozemlje

\section{INTRODUCTION}

Floristic investigations on the island of Korčula have a 160 year tradition (DE VISIANI, $1842,1847,1852,1872-1881$ ), while a detailed historical overview of research into the flora of the island has been presented by Trinajstić $(1995,2000)$. According to JERIČEvić et al. (2014), the total recorded number of plant taxa (species and infraspecific taxa) on the island of Korčula, including neighbouring islets, is 1063. Regarding the vegetation, 
some studies within the phytosociological scope recognised several plant associations of the three main groups of communities on the island: forest, halophytic and ruderal vegetation (cf. TrinajsTić, 1973, 1979, 1985, 1986). However, the level of knowledge on the vegetation of the island of Korčula is minimal, and the current state of the diversity in plant communities in practice remains to be determined.

Similarly, the vegetation of all islets in the Korčula archipelago, including the islet of Badija, is mostly unknown (cf. TRINAJSTIĆ 1985, and references therein; JAsPRICA et al., 2014a; Dolina et al., 2015). BARČIĆ (1942), within his BSc thesis, collected 11 phytosociological relevés on the islet. Among them, one relevé was made in the Aleppo pine wood and 10 relevés in the "Quercetum ilicis galloprovincialis" association. However, among the islets, only the flora of the islet of Badija has been investigated in any detail (BARčić, 1974a,b, 1978-1979). In these papers (op. cit.), the floristic data were mostly derived from herbarium material which had been collected before the Franciscans left the islet, as far back as 1949. According to these data, 382 taxa (species and infraspecific taxa) of vascular plants, including cultivated plants, have been recorded on the islet.

The aims of the present study were: i) to investigate the vegetation of the islet for the first time, ii) to present new records of vascular plant taxa for the islet. Additionally, the present study will provide a contribution towards a better understanding of the phytocoenoses that have colonised the islet, and to evaluate their levels of biodiversity in relation to the phytogeographical position and geomorphological characteristics.

\section{Study area}

The karstic islet of Badija (coordinates $42^{\circ} 57^{\prime} 20^{\prime \prime} \mathrm{N} 17^{\circ} 09^{\prime} 40^{\prime \prime} \mathrm{E}$ ) is the largest (surface area of $0.97 \mathrm{~km}^{2}$ ) in the Korčula archipelago, making it also the largest in Croatia. According to Duplančić et al. (2004) islets by definition have a surface area of less than $1 \mathrm{~km}^{2}$. It is located near the town of Korčula in south Croatia. The coast is low and rocky and has a total length of $4.158 \mathrm{~km}$. Sea depths around the islet are between 1.5 and $15 \mathrm{~m}$. The maximum height is $75 \mathrm{~m}$ a.s.l.

The first recorded mention of the islet was in 1368; it was inhabited by Franciscans from Bosnia from 1392 until after World War II when in 1949 the Franciscans were expelled, the monastery being converted into a sports centre and resort in 1950. The monastery and church on Badija, after more than 60 years of neglect and destruction of religious and cultural heritage, are now being gradually restored. Today the islet is not inhabited, although the monastery garden is regularly maintained and planted with a variety of cultivated species. In the summer months the islet is an attraction for tourists on daily trips.

It should be noted that fallow deer [Dama dama (Linnaeus, 1758)] were introduced to the islet in the late 1950s (Vojinović \& Miočić, 1994). The fallow deer is a ruminant and requires large amounts of plant food. It has been estimated that fallow deer prefer to peel the bark off Viburnum tinus (op. cit.). In addition, the richness and diversity of herbaceous and shrub layers that are rich in protein and carbohydrates, provide favourable conditions for the fallow deer population. In the early 80s, a large herd of 50-60 fallow deer was recorded but had been reduced by about a fifth by 1994 (Vojinović \& Miočić, 1994). The deer population density on the islet today is not known.

The study area belongs to the Mediterranean Region, Eastern Mediterranean Subregion, Adriatic Province, and Epiro-Dalmatian Sector (Rivas-Martínez et al., 2004). Geologically, the ground consists of Senonian limestones (Korolija et al., 1997). The predo- 
minant soil type is calcocambisol (MARtinović, 1986). Terra Rossa has been developed on the interior level areas.

According to the Köppen classification, the climate of the island of Korčula is of type Csa (ŠEgota \& FilipčIĆ, 2003). Average annual air temperature is $16.8^{\circ} \mathrm{C}$ and precipitation ranges from 1000-1250 $\mathrm{mm} \mathrm{yr}^{-1}$ (data from the nearby town of Korčula station for 1981-2007, KRKLEC et al., 2011). The highest daily average temperature is $25.9^{\circ} \mathrm{C}$ in July, and the lowest is below $9.1^{\circ} \mathrm{C}$ in February. On average, the relative air humidity is $71.6 \%$. The greatest rainfall is in the period from October to March with the average monthly rainfall from 80 to $150 \mathrm{~mm}$. In the period from June to August the total rainfall varies between 90 and $135.0 \mathrm{~mm}$. Southern winds prevail throughout the year. The entire area is characterized by frequent sunny weather, with the most westerly parts having in excess of 2700 hours of sunshine a year, while the east has about 300 hours less (JAsPRICA, 2010). The area has a Mediterranean pluviseasonal-oceanic bioclimate, and it is situated within the lower meso-Mediterranean belt (JERIČEvić et al., 2014; sensu RIVAs-MaRTíNEZ et al., 2004).

The greater part of the islet's surface area is covered by macchia. Phytogeographically, the islets belong to the Euri-Mediterranean vegetation zone of the alliance Fraxino orniQuercion ilicis (sensu Biondi et al., 2013).

The islet has been protected as being of natural value in the category of Significant Landscape from 1969. It belongs, as a part of the island of Korčula, to the Important Plant Areas (IPAs) in Croatia (JAsPricA, 2010). In addition, the islet is part of the NATURA 2000 European Ecological Network (AnONYmous, 2013a, 2015) of sites important for birds (site code HR1000036: Middle Dalmatian islands and the Pelješac peninsula).

\section{MATERIAL AND METHODS}

\section{Flora}

The study was carried out in the period between October 2014 and July 2015 in all seasons. Floristic surveys were conducted using the standard method described by NIкоLіć et al. (1998) and Niкоцić (2006). The research includes indigenous taxa, but also included in the list are cultivated taxa where encountered out of a cultivated environment. The taxa that are now grown in culture (in the monastery garden) are not inventoried.

Taxa were determined using the standard determination keys, books and guides: Bonnier (1911-1935), Fiori (1923-1929), HAYeK (1924-1933), Hegi (1936-1987), Tutin et al. (1968-1980, 1993), Horvatić \& Trinajstić (1967-1981), Trinajstić (1975-1986), Javorka \& Csapody (1975), Pignatti (1982), Domac (1994), Delforge $(1995,2006)$, etc.

Plant nomenclature follows Nikolić (2015), except for Juniperus phoenicea L. ssp. turbinata (Guss.) Nyman and Teucrium capitatum L., where the Euro+Med Plantbase were applied (Euro+Med, 2006-2016). Only those taxa that have not previously been reported in the literature (BARčIć, 1974, TRINAJSTIĆ, 1985) are reported in this study. Taxa listed in the Red Book of Vascular Flora of Croatia (Nikolić \& Topić, 2005, Nikolić, 2015) are marked with their corresponding IUCN status (IUCN, 2014). In addition, strictly protected taxa (SP) as defined by Croatian Law are also denoted (ANONYMous, 2013b,c). Any invasive alien taxa (IAS) have been defined according to Nikolić et al. (2014). 


\section{Vegetation}

Phytosociological analysis allowed the detection of some associations, understanding of their ecological characteristics and definiitin of their syntaxonomic position. Vegetation was studied in accordance with the principles of the Braun-Blanquet approach (Braun-Blanquet, 1964). Only stands with at least the minimum area recommended for particular types of vegetation were investigated (cf. CHYtrÝ \& OtÝPKová, 2003). GaussKrüger coordinates ( $5^{\text {th }}$ zone), altitude, aspect and slope were determined for each relevé.

The system of characterizing species was derived from Ilijanić \& Hećimović (1982), Hećimović (1984), Horvat et al. (1974), Jasprica et al. (2014b, 2015a, and references therein), and only partly from Brullo \& GuArino (1998) and Brullo et al. $(2007,2008)$. For the arrangement of the plant associations in the upper hierarchic levels (see the syntaxonomic listing) the scheme proposed by Biondi et al. (2014) for Italy was mainly followed. The survey covers the entire surface of the islet and all habitat types. Altogether, 52 phytosociological relevés were collected. The resulting tables (Tabs. 1-6) were slightly rearranged manually. In the tables, for each taxon, frequencies are given as percentages (\%). If only four or fewer relevés were available, only the presence of taxa in a given association is indicated. Place and date of relevés are listed in the Appendix 1. In addition, classification of the vegetation units distinguished into habitat types of Annex I of the Habitats Directive 92/43/EEC were done according to List of NATURA 2000 habitats declared by Croatian Government (AnONymous, 2014). Priority habitats are denoted by an asterisk $\left({ }^{*}\right)$.

In order to verify the traditional syntaxonomic system, the relevés were classified by numerical methods. The matrix consists of 105 species $\times 52$ samples (relevés). BrauN-

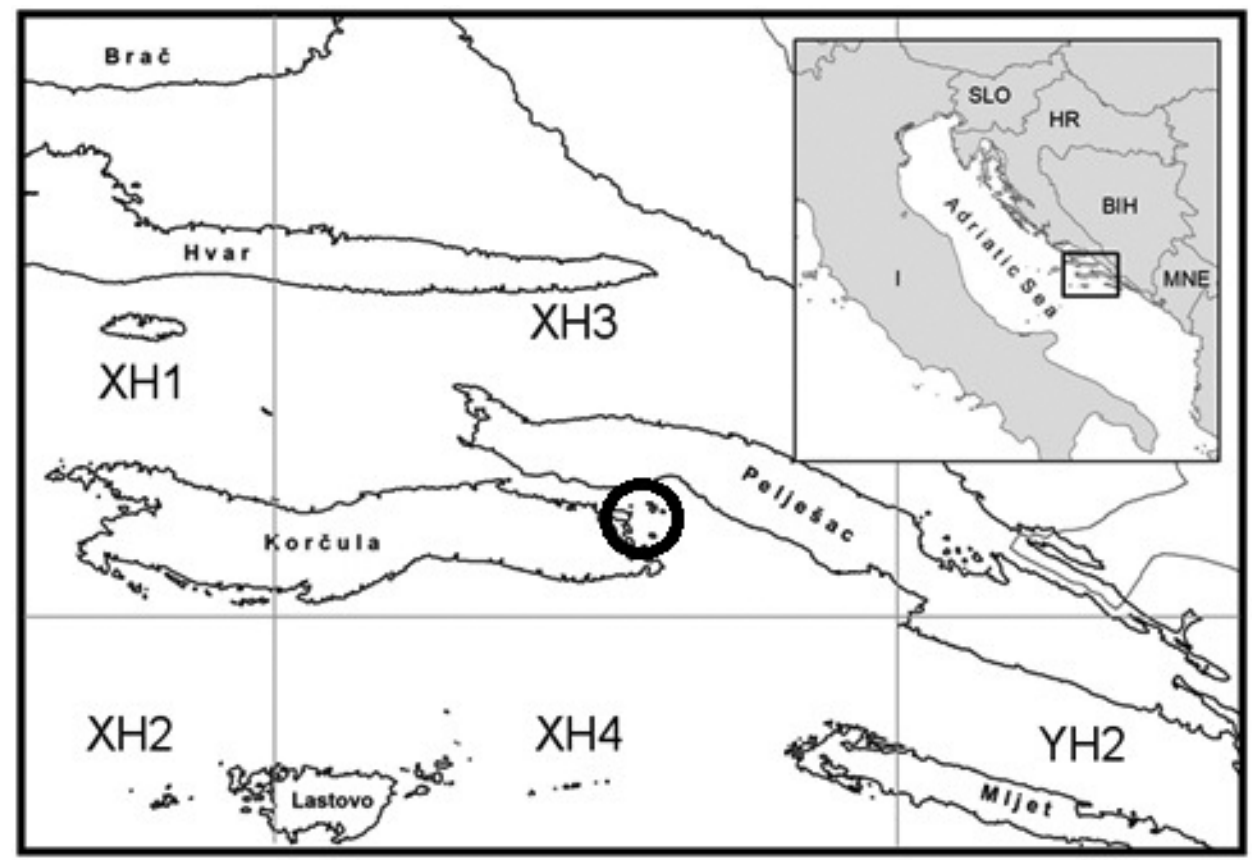

Fig. 1. Geographical position of the islet (circle) (Abbreviations: SLO: Slovenia; HR: Croatia; BIH: Bosnia and Herzegovina; MNE: Montenegro; I: Italy). 


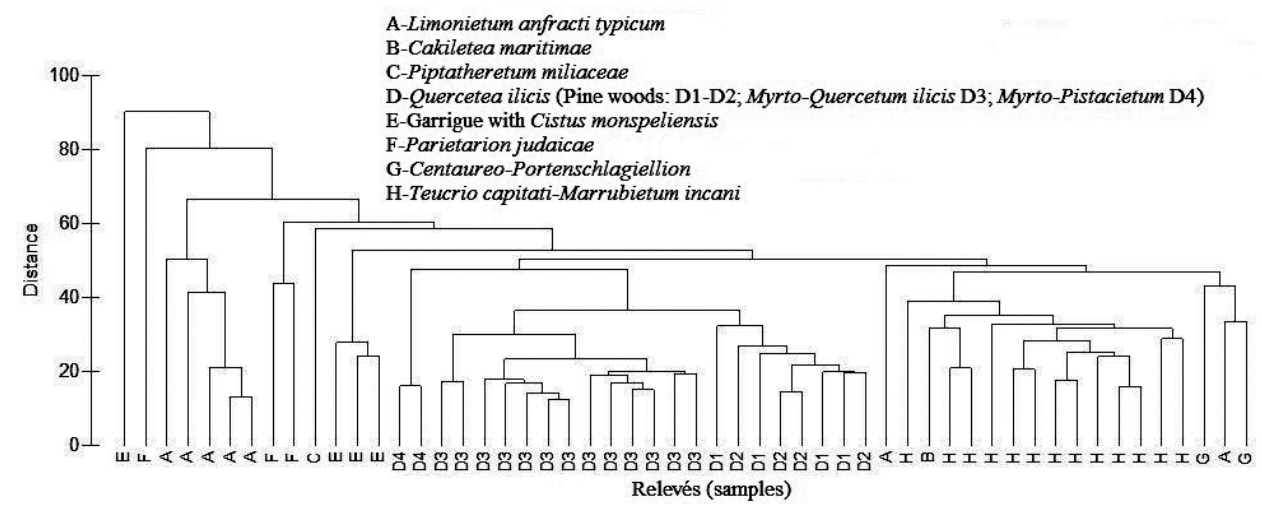

Fig. 2. Dendrogram of the relevés.

Blanquet (1964) values were transformed according to van Der MAAREL (1979). An agglomerative, hierarchical clustering algorithm based on Euclidean distances and Ward's method for determination of group linkages was used (McCunE \& MefFord, 2006). Differences between groups obtained in the classification were tested by analysis of similarities (ANOSIM). For these purposes the PC-ORD ver. 5 and PRIMERv6 software packages (McCune \& Mefford, 2006, Clarke \& Gorley, 2006) were used.

\section{RESULTS AND DISCUSSION}

\section{Vegetation}

Altogether, eight associations, one subassociation and three stands (communities) were determined within nine vegetation classes (Tabs. 1-6, Fig. 2).

Their syntaxomic survey is as follows:

POSIDONIETEA OCEANICAE Hartog 1976 ex Géhu in Bardat, Bioret, Botineau, Boullet, Delpech, Géhu, Haury, Lacoste, Rameau, Royer, Roux et Touffet 2004

+Posidonietalia oceanicae Hartog 1976

*Posidonion oceanicae Braun-Blanquet, Roussine et Nègre 1952

\section{Posidonietum oceanicae (Funk 1927) Molinier 1958}

CAKILETEA MARITIMAE Tüxen et Preising ex Braun-Blanquet et Tüxen 1952

+ Euphorbietalia peplis Tüxen 1950

*Euphorbion peplis Tüxen 1950

\section{Euphorbio pineae-Glaucietum flavi Horvatić 1934}

CRITHMO MARITIMI-STATICETEA Braun-Blanquet in Braun-Blanquet, Roussine et

Nègre 1952 em. Biondi 2007

+Crithmo maritimi-Staticetalia Molinier 1934

*Crithmo maritimi-Staticion Molinier 1934

Limonietum anfracti subass. typicum Ilijanić et S. Hećimović 1982

QUERCETEA ILICIS Braun-Blanquet in Braun-Blanquet, Roussine et Nègre 1952

+Quercetalia ilicis Braun-Blanquet ex Molinier 1934 
${ }^{*}$ Fraxino orni-Quercion ilicis Biondi, Casavecchia et Gigante ex Biondi, Casavecchia et Gigante in Biondi, Allegrezza, Casavecchia, Galdenzi, Gigante et Pesaresi 2013 Myrto communis-Quercetum ilicis (Horvatić 1963) Trinajstić (1976) 1985

+Pistacio lentisci-Rhamnetalia alaterni Rivas-Martínez 1975

*Oleo sylvestris-Ceratonion siliquae Braun-Blanquet ex Guinochet et Drouineau 1944 Myrto communis-Pistacietum lentisci (Molinier 1954) Rivas-Martínez 1975

+Pinetalia halepensis Biondi, Blasi, Galdenzi, Pesaresi et Vagge in Biondi, Allegrezza,

Casavecchia, Galdenzi, Gasparri, Pesaresi, Vagge et Blasi 2014

*Pistacio lentisci-Pinion halepensis Biondi, Blasi, Galdenzi, Pesaresi et Vagge in Biondi,

Allegrezza, Casavecchia, Galdenzi, Gasparri, Pesaresi, Vagge et Blasi 2014

Querco ilicis-Pinetum halepensis Loisel 1971

Pistacio lentisci-Pinetum halepensis De Marco, Veri et Caneva 1984

CISTO CRETICI-MICROMERIETEA JULIANAE Oberdorfer ex Horvatić 1958 (=ERICO-

CISTETEA Trinajstić 1985)

+Cisto cretici-Ericetalia manipuliflorae Horvatić 1958

*Cisto cretici-Ericion manipuliflorae Horvatić 1958

Garrigue with Cistus monspeliensis

PARIETARIETEA JUDAICAE Oberdorfer 1977

+Tortulo-Cymbalarietalia Segal 1969

* Parietarion judaicae Segal 1969

ASPLENIETEA TRICHOMANIS (Braun-Blanquet in Meier et Braun-Blanquet 1934)

Oberdorfer 1977

+ Centaureo dalmaticae-Campanuletalia pyramidalis Trinajstić 1980

*Centaureo cuspidatae-Portenschlagiellion ramosissimae Trinajstić 1980

THERO-BRACHYPODIETEA RAMOSI Braun-Blanquet in Braun-Blanquet 1947)

+Cymbopogono hirti-Brachypodietalia ramosi Horvatić 1963

*Cymbopogono hirti-Brachypodion ramosi Horvatić 1963

Piptatheretum miliaceae Horvatić (1956) 1958 (=Oryzopsetum miliaceae)

STELLARIETEA MEDIAE Tüxen, Lohmeyer et Preising in Tüxen ex von Rochow 1951

CHENOPODIO-STELLARIENEA Rivas Goday 1956

+Chenopodietalia muralis Braun-Blanquet in Braun-Blanquet, Gajewski, Wraber et Walas 1936

*Chenopodion muralis Braun-Blanquet in Braun-Blanquet, Gajewski, Wraber et Walas 1936

Teucrio capitati-Marrubietum incani Jasprica et Milović 2016, ass. nova hoc loco (holotypus rel. 4 in Tab. 6)

\section{DESCRIPTION OF THE ASSOCIATIONS}

\section{The submerged beach}

Posidonietum oceanicae [NATURA 2000 habitat code 1120 - Posidonia beds (Posidonion oceanicae)]

This is the site of the phanerogamic seagrass Posidonia oceanica (endemic to the Mediterranean), which has developed on the moving seabed between $2 \mathrm{~m}$ and 15 in depth. 
This seagrass constitutes an effective barrier to wave motion, and thus effectively protects the shoreline from erosion and stabilises the sea bottom; moreover, it is a breeding site for many species ant is one of the main sources of oxygenation of the environment.

\section{The shingle beach}

Euphorbio pineae-Glaucietum flavi [NATURA 2000 habitat code 121 - Annual vegetation of drift lines (Euphorbion peplis)]

This therophytic halo-nitrophilous pioneer vegetation from the Shingle beach is only fragmentarily developed. It occupies a very small surface area near the port. The Glaucium flavum is missing in the relevé. The floristic composition of the association was as follows [Gauss-Krüger coordinates $X=5677025 \mathrm{Y}=4758542$; date 21.3.2015; plot size $20 \mathrm{~m}^{2}$; altitude 0-1 m a.s.l.; vascular plant cover $40 \%$; geological type: limestone; soil: brown littoral]: Euphorbia pinea (3), Datura inoxia (1), Inula verbascifolia (+), Vitex agnus-castus (+), Senecio bicolor ssp. cineraria (+), Arum italicum (+), Marrubium incanum (+), Diplotaxis muralis (+), Teucrium capitatum (+), Ferula communis (+), Taraxacum officinale (r), Cistus monspeliensis (r), Oxalis corniculata $(\mathrm{r})$.

\section{The low rocky coast}

Limonietum anfracti typicum [NATURA 2000 habitat code 124 - Vegetated sea cliffs of the Mediterranean coasts with endemic Limonium spp. (Crithmo maritimi-Staticion)]

The low rocky coast is subjected to the actions of the marine aerosol and is colonised by halo-chasmophytic vegetation of the Limonietum anfracti typicum subassociation (Tab. 1). The subassociation is characterised by Limonium dictyophorum (=L. anfractum), a species endemic to the southern coast of the eastern Adriatic that forms dense lowspreading formations that colonise the cracks in the rocks. The rocky coasts are largely exploited as holiday beaches.

More recently, Limonium leprosorum Bogdanović et Brullo, a species belonging to $L$. cancellatum group, was described and found on the Pelješac peninsula and the island of Korčula including some nearby islets (Bogdanović \& BRULLO, 2015). However, further research is required to demonstrate the presence of this taxon on the islet.

\section{The Holm Oak forest}

Myrto communis-Quercetum ilicis [NATURA 2000 habitat code 934 - Quercus ilex and Quercus rotundifolia forests]

This association covers more than $70 \%$ of the islet's surface area. It is characterised by the absence of any deciduous species and represents the driest forest or macchia with Quercus ilex on the eastern Adriatic coast (Tab. 2, rels. 9-21). In our case, a hornbeam (Ostrya carpinifolia) was recorded in the association (Tab, 2, rel. 15). In the study area, the association is developed as macchia of 3 to $5 \mathrm{~m}$ height. The ground layer has extremely low vegetation cover (up to $10 \%$ ) and consists of a low number of species, of which the most common was Cyclamen repandum. In addition, some climbing species are completely missing (e.g. Lonicera implexa, etc.). In our case, the extremely low herb layer coverage cannot be attributed to potentially low light intensity as a limiting factor (e.g. VuKELIĆ, 2012), but rather the presence of the large population of fallow deer (cf. BARČIć, 1942). Deer exhibit direct and indirect effects on forest communities by reducing host plant densities or altering forest structure (Vojinović \& Miočıć, 1994; Shipley, 1999; RoONEY, 2001; etc.). 


\section{Low macchia}

\section{Myrto communis-Pistacietum lentisci}

The association forms small patches between halophytic vegetation (Limonietum anfracti typicum) and the Pistacio lentisci-Pinetum halepensis association (Tab. 2, rels. 22-23). This association has developed as low (mostly between 1 and $1.5 \mathrm{~m}$ ) and dense shrub formations on the south-eastern part of the islet. It covers larger surface areas on some islets along the northern coast of the Pelješac peninsula (JASPRICA et al., 2014a, 2015b). Due to the influences of the strong southern winds, it is mostly composed of only a small number of plant species.

The Aleppo pine forests [NATURA 2000 habitat code 9540 - Mediterranean pine forests with endemic Mesogean pines]

The Aleppo pine forests refer to the associations Querco ilicis-Pinetum halepensis and Pistacio lentisci-Pinetum halepensis. These associations cover more than $20 \%$ of the islet's surface area.

\section{Querco ilicis-Pinetum halepensis}

The association occupies a very limited surface area on the northern side of the monastery (Tab. 2, rels. 1-4). Quercus ilex is developed in the brush layer and Pinus halepensis is the dominant taxon. Despite the strong anthropogenic influence (clearing, grazing) (cf. BARčıć, 1942), it has value from the aesthetic and ecological point of view.

\section{Pistacio lentisci-Pinetum halepensis}

This association is developed over the area north of the monastery and partly on the eastern part of the islet (Tab. 2, rels. 5-8). The number of plant taxa in the association is about five times smaller than in those reported from the Mid-Adriatic (Trinajstić \& Kamenjarin, 1998, 2001). On the islet, some common taxa from this association (e.g. Lonicera implexa, Juniperus oxycedrus ssp. macrocarpa, Viburnum tinus, Rubia peregrina, etc.) are missing. Furthermore, among companions, Brachypodium retusum is a quite sporadic taxon. It can be assumed that the association has developed here on the remains of longabandoned olive groves. The negative impact of deer on the structure and floral composition of the wood cannot be ignored.

\section{Garrigue with Cistus monspeliensis}

Garrigue covers a very small surface area on the islet. It is developed in the northwestern part of the islet on the area formerly under crops (at the locality of Lokva) and near the monastery garden. This association does not have a floral composition typical of garrigue, and, alongside Cistus monspeliensis, Pistacia lentiscus and Teucrium capitatum were the most abundant (Tab. 3). The presence of some characteristic species of ruderal and weed vegetation (Stellarietea media, Artemisietea vulgaris) suggests that the environment is still highly affected by man. The highly anthropogenic composition of Cistus monspeliensis garrigue within the study area does not permit the provision of a precise syntaxonomical reference in terms of association.

Within garrigue of the Cisto cretici-Micromerietea julianae (=Erico-Cistetea) class, the Cisto-Ericetum arboreae Horvatić 1958 (=Erico arboreae-Arbutetum unedonis Allier \& Lacoste 1980, p.p.) association previously reported by BARČIć (1978-1979), though without phytosociological relevés, was not found on the islet during this study. 


\section{Wall vegetation}

Parietarion judaicae [NATURA 2000 habitat code 8210 - Calcareous rocky slopes with chasmophyic vegetation (Tortulo-Cymbalarietalia)]

Wall vegetation is included in chasmophytic synanthropic vegetation of the Parietarietea judaicae class. On the islet, this vegetation was only found at three sites near the monastery garden (Tab. 4). In general, some of the characteristic taxa of thermophilous vegetation (Umbilicus horizontalis, Cymbalaria muralis, Asplenium ruta-muraria, etc.) mainly linked to Parietarion judaicae or upper syntaxa are not found on the islet (sensu Brullo \& Guarino, 1998).

Although Corydalis acaulis has its primary habitats in rocky sites within the order Centaureo dalmaticae-Campanuletalia pyramidalis (Trinajstić, 2008; Milović, 2015), here it occurs exclusively on the islet's walls. Further, the population of this species is estimated to consist of fewer than 30 individuals.

\section{Thermophilous chasmophytic vegetation}

Centaureo cuspidatae-Portenschlagiellion ramosissimae [NATURA 2000 habitat code 8210 Calcareous rocky slopes with chasmophyic vegetation (Centaureo-Campanuletalia)]

The rocky vegetation is characterized by a high abundance of Inula verbascifolia and Campanula pyramidalis on small rocky surfaces at higher altitudes on the islet (Tab. 5). Some species from Quercetea ilicis (Ephedra fragilis ssp. campylopoda) and Thero-Brachypodietea ramosi (Allium subhirsutum) have a relatively significant degree of coverage. Species of wall vegetation are completely missing.

Piptatheretum miliaceae (=Oryzopsetum miliaceae) [NATURA 2000 habitat code $6220^{*}$ - Pseudosteppe with grasses and annuals Thero-Brachypodietea]

This association occurs within the monastery garden. The floristic composition of the association was as follows [Gauss-Krüger coordinates $\mathrm{X}=5676843 \mathrm{Y}=4758731$; date 4.7.2015; plot size $15 \mathrm{~m}^{2}$; altitude $1 \mathrm{~m}$ a.s.l.; vascular plant cover $100 \%$; geological type: limestone; soil: brown littoral soil]: Piptatherum miliaceum (4), Rubus ulmifolius (1), Conyza canadensis (1), Lactuca serriola (1), Delphinium staphisagria (1), Medicago sativa (+).

Within the Thero-Brachypodietea ramosi class, the Brachypodio ramosi-Trifolietum stellati Horvatić in Horvat et al. 1974 association previously reported by BARČIć (1978-1979), but not documented by phytosociological relevés, was not found on the islet. Currently these open rocky habitats, previously observed in the form of a narrow strip between macchia and halophytic vegetation, do not exist on the islet.

Teucrio capitati-Marrubietum incani, ass. nova hoc loco (Tab. 6, holotypus rel. 4, Fig. 3)

This newly proposed association is mostly developed on the sites of previous cereal crops (wheat, barley, oat, rye) on the nitrophilous soils. This vegetation was also found near the coast in untilled habitats. The characteristic taxa Marrubium incanum and Delphinium staphisagria (the latter an endangered and strictly protected taxon in Croatia), are in relations of co-dominance with Teucrium capitatum. The vegetation is connected with the dynamic series of Fraxino orni-Quercion ilicis and Oleo sylvestris-Ceratonion siliquae (Fig. 2; and Brullo et al., 2007), and has been observed on the edges of this patch partially overgrown by garrigue with Cistus monspeliensis or macchia. This association differed from the Scolymo-Marrubietum incani Horvatić et Hodak 1965, distributed in the Illyrian-Adriatic Karst area, and mostly linked with the dynamic series of the TheroBrachypodietea ramosi (JAsPRICA \& CARIĆ, 2002). The association is subordinated to the 


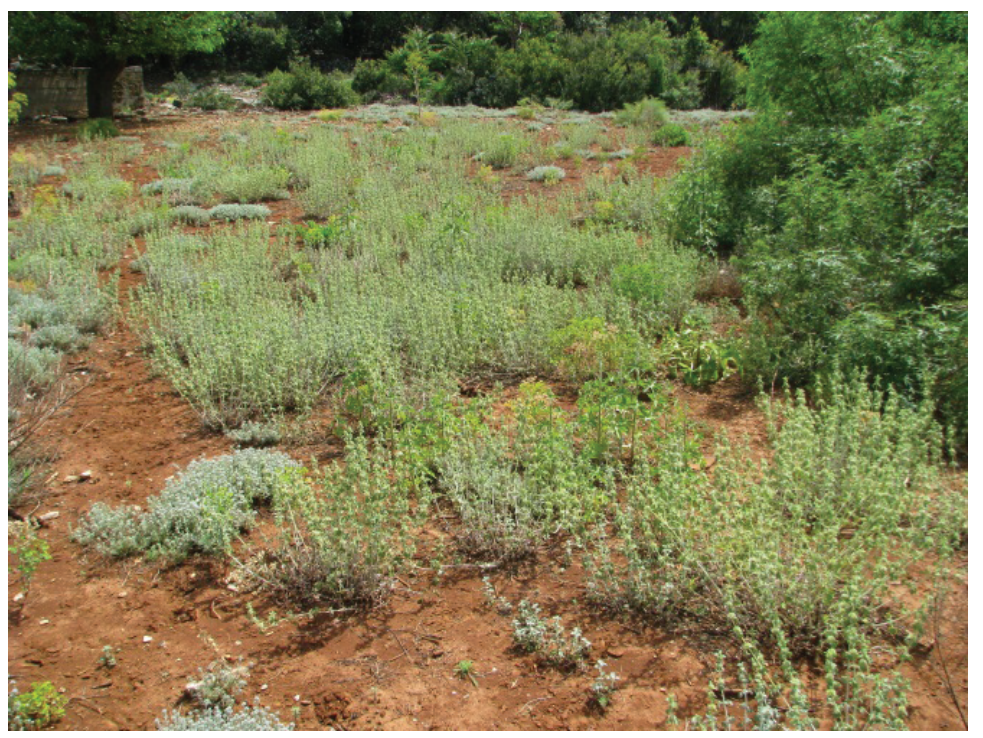

Fig. 3. The Teucrio capitati-Marrubietum incani Jasprica et Milović 2016 association, ass. nova hoc loco, on the islet of Badija.

Chenopodietalia muralis order, which represents highly nitrophilous pioneer ruderal vegetation on habitats that are well exposed and sunny, and is found in Mediterranean regions (cf. PANDžA et al., 2005; Biondi et al., 2014).

\section{Floristic notes}

In 2014 and 2015, 27 new vascular plant taxa (26 species and one subspecies) were recorded on the islet. They are [abbreviations: IAS - invasive alien species, LC - Least Concern taxon, SP - strictly protected taxon]: Ailanthus altissima (Mill.) Swingle (IAS), Aphanes arvensis L., Aster squamatus (Spreng.) Hieron (IAS), Atriplex prostrata Boucher ex DC. in Lam. et DC., Bromus rigidus Roth, Carpobrotus acinaciformis (L.) L. Bolus (IAS), Chenopodium album L., Chenopodium murale L. (DD), Coronilla varia L., Diplotaxis muralis (L.) DC., Filago vulgaris Lam., Galium murale (L.) All., Hedera helix L., Inula conyza DC., Lactuca serriola L., Lactuca viminea (L.) J. et C.Presl, Lolium multiflorum Lam., Medicago sativa L., Opuntia ficus-indica (L.) Miller (IAS), Ostrya carpinifolia Scop., Plantago coronopus L., Plantago holosteum Scop. (LC), Posidonia oceanica (L.) Delile (SP), Teucrium capitatum L., Trifolium arvense L., Verbascum blattaria L. and Vicia angustifolia L. ssp. angustifolia.

Thus the entire flora of the islet of Badija now consists of 409 vascular plant taxa. Of the newly recorded taxa, four are considered to be invasive. One taxon is strictly protected by statute. The Red List categories Least Concern (LC) and Data Deficient (DD) are assigned to one species in each.

In this study, some taxa previously recorded on the islet have not been confirmed. These taxa can be categorized into three groups: i) taxa of the coastal halophytic communities (Salicornia perennans ssp. perennans, Salsola soda, S. kali, Glaucium flavum, Cakile maritima, etc.), ii) taxa of the dry grasslands including olive groves (mainly Orchidaceae, Hermodactylus tuberosus, etc.), iii) nitrophilous and ruderal taxa (Agrostemma githago, etc.). 


\section{CONCLUSIONS}

The sea bed is colonized by a dense population of submerged Posidonia oceanica. In the part of the islet near the sea, the coast is colonized by halophytes. There is a vegetation belt with locally large stands of Limonium dictyophorum. Inward from this belt vegetation with Euphorbia pinea can be found preceding the low macchia dominated by Pistacia lentiscus. In the intermediate part, between the Quercus ilex forest and low macchia, on the southern slopes and at lowest altitudes, there is a belt of pine woods. The garrigue and nitrophilous vegetation are the result of a long history of disturbance. The latter is connected with the dynamic series of Fraxino orni-Quercion ilicis vegetation. Near the top of the islet, the slope is not steep and small vertical rocky cliffs are present with only a few chasmophytic species, while wall vegetation is found only in the area of high visitor attendance.

The vegetation on the islet is under significant anthropogenic influence, primarily due to the presence of fallow deer. Furthermore, part of the open rocky habitat has become overgrown during the last several decades. On the other hand, previously well developed nitrophilous and ruderal habitats (crops, stables for livestock, etc.) are now scarce.

Classification of the distinguished vegetation units into habitat types according to Habitats Directive 92/43/EEC revealed nine habitat types. These communities are an important part of the Croatian natural heritage and they must in fact be protected according to international obligations. However, management plans must ensure that the land of these types of habitat is used in a sustainable way. The islet still meets the criteria for Significant Landscape level of protection, but the authorities should take measures regarding the regulation of the size of the population of deer on the islet. Further infringement of the islets with respect to activities carried out during the summer (daily trips for recreation) is not to be expected.

\section{ACKNOWLEDGEMENTS}

Research funding came from the Public Institution for Management of Protected Natural Values in the Dubrovnik-Neretva County, Dubrovnik. We thank Dr Marija Crnčević for her very useful contributions and help. Special thanks go to Friar Dr Stipe Nosić, Guardian of the Friars Minor Franciscan Monastery in Dubrovnik, who has kindly sent us the articles of Friar Berard Barčić. The authors thank Mirjana Jeričević and Nebojša Jeričević for their support during the field research. Thanks also are extended to Steve Latham (UK) for improving the English. We would like to thank the two anonymous reviewers and the editors for their constructive comments on an earlier version of this manuscript.

Received July 28, 2015

\section{REFERENCES}

Anonymous, 2013a: Uredba o ekološkoj mreži [Regulation of Ecological Network NATURA 2000 Croatia]. Narodne novine 124/2013.

Anonymous, 2013b: Zakon o zaštiti prirode [The Nature Protection Act]. Narodne novine 80/2013.

Anonymous, 2013c: Pravilnik o strogo zaštićenim vrstama [The Regulation on strictly protected species]. Narodne novine 144/2013. 
Anonymous, 2014: Pravilnik o popisu stanišnih tipova, karti staništa te ugroženim i rijetkim stanišnim tipovima [The Ordinance on habitat types, habitat map and threatened and rare habitat types]. Narodne novine 88/2014.

Anonymous, 2015: Uredba o izmjenama Uredbe o ekološkoj mreži [Regulation on amending the Regulation of Ecological Network NATURA 2000 Croatia]. Narodne novine 105/2015.

BARČIć, B., 1942: Biljnogeografski odnosi otoka Badije [Phytogeographical position of the islet of Badija]. Domaći sastav za profesorski ispit. Filozofski fakultet Sveučilišta u Zagrebu.

BARčić, B., 1974a: Flora otočića Badije [Flora of the islet of Badija]. Acta Bot. Croat. 33, 191-203.

Barčić, B., 1974b: Biljka "goli čovjek" u hrvatskoj flori [Eastern Strawberry in the flora of Croatia] Priroda 63(10), 292-293.

BARČIĆ, B., 1978-1979: Biljni pokrov otoka Badije [Vegetation cover of the islet of Badija]. Priroda 67(6), 175-177.

Biondi, E., Allegrezza, M., Casavecchia, S., Galdenzi, D., Gigante, D. \& Pesaresi, S., 2013: Validation of some syntaxa of Italian vegetation. Plant Biosyst. 147, 186-207.

Biondi, E., Blasi, C., Allegrezza, M., Anzellotti, I., Azzella, M. M., Carli, E. et al., 2014: Plant communities of Italy: The Vegetation Prodrome. Plant Biosyst. 148, 728-814.

Bogdanović, S. \& Brullo, S., 2015: Taxonomic revision of the Limonium cancellatum group (Plumbaginaceae) in Croatia. Phytotaxa 215(1), 1-87.

Bonnier, G., 1911-1935: Flore compléte illustrée en couleurs de France, Suisse et Belgiqe [Complete flora illustrated in colour of France, Switzerland and Belgium]. Neuchatel, Paris et Bruxelles.

Braun-Blanquet, J., 1964: Pflanzensoziologie. Grundzüge der Vegetationskunde [Plant sociology. Basic course of Vegetation Science]. 3. New York, USA: Springer-Verlag.

Brullo, S. \& Guarino, R., 1998: Syntaxonomy of the Parietarietea judaicae class in Europe. Ann. Bot. 56, 109-146.

Brullo, S., Giusso Del Galdo, G., Guarino, R. \& Minissale, P., 2007: A survey of the weedy communities of Sicily. Ann. Bot. 7(n.s.), 127-161.

Brullo, S., Gianguzzi, L., La Mantia, A. \& Siracusa, G., 2008: La classe Quercetea ilicis in Sicilia [The Quercetea ilicis class in Sicily]. Boll. Acc. Gioenia Sci. Nat. Catania 41, 1-80.

Clarke, K. R. \& Gorley, R. N., 2006: PRIMER v6: User Manual/Tutorial. PRIMER-E, Plymouth.

Chyтrर́, M. \& OтÝPкоvé, Z., 2003: Plot sizes used for phytosociological sampling of European vegetation. J. Veg. Sci. 14, 563-570.

Delforge, P. (ed.), 2006: Orchids of Europe, North Africa and the Middle East (3rd ed.), English translation.A. \& C. Black, London.

Delfroge, P., 1995: Orchids of Britain \& Europe. Harper Collins Publishers. London.

Dolina, K., Jasprica, N. \& Milović, M., 2015: Vegetation of the islet of Vrnik, southeastern Adrioatic: Preliminary results. IN: Book of Abstract of the $36^{\text {th }}$ Meeting of the Eastern Alpine and Dinaric Society for Vegetation Ecology. ŠKvorc, Ž., Franjıć, J. \& Krstonošić, D. (eds.), Osijek, Croatia, June 17-20, 2015.

Domac, R., 1994: Flora Hrvatske [Flora of Croatia]. Priručnik za određivanje bilja. Zagreb.

Duplančić Leder, T., Ujević, T. \& ČAla, M., 2004: Duljine obalne crte i površine otoka na hrvatskom dijelu Jadranskog mora određene s topografskih karata mjerila 1:25000 [Coastline length and surface areas of islands in the Croatian part of the Adriatic Sea determined from the topographic maps on the scale of 1:25000]. Geoadria 9(1), 5-32.

Euro+Med, 2006-2016: Euro+Med PlantBase - the information resource for Euro-Mediterranean plant diversity. Published on the Internet http://ww2.bgbm.org/EuroPlusMed/ [Accessed March 7, 2016].

FIorI, A., 1923-1929: La Nuova Flora Analitica d'Italia [New analytical flora of Italy]. 1-2. Firenze.

HayeK, A., 1924-1933: Prodromus florae Peninsulae Balcanicae. 1-3. Dahlem bei Berlin.

Hećımović, S., 1984: Vegetation der Inseln Bobara und Mrkan [Vegetation of the islets of Bobara and Mrkan]. The Eighteenth Symposium of the Eastern Alpine and Dinaric Society for Vegetation Ecology. Acta Bot. Croat. 43, 109-118.

Hegr, G., 1936-1987: Illustrierte Flora von Mittel-Europa [Illustrated flora of Central Europe] (2 $2^{\text {nd }}$ ed.), München.

Horvat, I., Glavač, V. \& Ellenberg, H., 1974: Vegetation Südosteuropas [Vegetation of south-eastern Europe]. Stuttgart: Gustav Fischer Verlag. 
Horvatić, S. \& Trinajstić, I. (eds.), 1967-1981: Analitička flora Jugoslavije 1 [Analytical flora of Yugoslavia 1]. Šumarski fakultet, Sveučilišna naklada Liber. Zagreb.

Ilijanić Lj. \& Hećımović S., 1982: Das Limonietum anfracti, eine neue Assoziation des Verbandes CrithmoLimonion Molinier 1934 [The Limonietum anfracti, a new association of the Crithmo-Limonion Molinier 1934 alliance]. Acta Bot. Croat. 41, 87-92.

IUCN, 2014: Guidelines for Using the IUCN Red List Categories and Criteria. Version 11. Prepared by the Standards and Petitions Subcommittee. Downloadable from http://www.iucnredlist.org/documents/RedListGuidelines.pdf

JAspricA, N., 2010: Korčula. In: Botanički važna područja Hrvatske [Important Plant Areas in Croatia]. Nikolıć, T., Topić J. \& Vuković, N. (eds.), Prirodoslovno-matematički fakultet Sveučilišta u Zagrebu i Školska knjiga d.o.o, Zagreb, 192-97.

JASPRICA, N. \& CARIć, M., 2002: Vegetation of the natural park of Hutovo Blato (Neretva river delta, Bosnia and Herzegovina). Biologia, Bratislava 57, 505-516.

Jasprica, N., Kovačić, S. \& Dolina, K., 2014a: Vegetation of the islands of the Pelješac peninsula archipelago (South Croatia, eastern Adriatic). In: Book of Abstract of $23^{\text {rd }}$ International Workshop of the European Vegetation Survey. ČArni, A., Juvan, N. \& Ribeiro, D. (eds.). Ljubljana: Jovan Hadži Institute of Biology ZRC SAZU, Anton Melik Geographical Institute ZRC SAZU, Ljubljana, May 8-12, 2014.

Jasprica, N., Bogdanović, S., Dolina, K., Ruščić, M., PAndža, M. \& Kovačić, S., 2014b: Syntaxonomy of Arundo stands along the eastern Adriatic coast. Plant Biosyst. DOI: 10.1080/11263504.2014.990942.

Jasprica, N., ŠKvorc, Ž., Dolina, K., Ruščić, M., Kovačić, S. \& FranjIĆ, J., 2015a: Composition and ecology of the Quercus coccifera L. along the eastern Adriatic coast (NE Mediterranean). Plant Biosyst. DOI: 10.1080/11263504.2014.1001461.

Jasprica, N., Dolina, K. \& Milović, M., 2015b: Flora and vegetation of three islets in south Croatia, NE Mediterranean. In: Book of Abstract of the $36^{\text {th }}$ Meeting of the Eastern Alpine and Dinaric Society for Vegetation Ecology. ŠKvorc, Ž., Franjıć, J. \& Krstonošı́, D. (eds.), Osijek, Croatia, June 17-20, 2015.

JAVORKA, S. \& CsAPODY, V., 1975: Iconographia florae partis Austro-orientalis Europae centralis. Akadémiai Kiadó, Budapest.

JeričEviĆ, M., JeričEvić, N. \& JAspricA, N., 2014: Floristic novelties from the island of Korčula and peninsula of Pelješac (South Croatia). Nat. Croat. 23(2), 241-253.

Korolija, B., Borović, I, Grimani, I., Marinčić, S., Jagačić, T., Magaš, N. \& Milanović, M., 1977: Osnovna geološka karta SFRJ 1:100000 [General Geological Map of SFRY 1:100000], Tumač za listove Lastovo K33-46, Korčula K33-47 i Palagruža K33-57. 5-53, Inst. za geol. istraž. Zagreb, Savezni geol. zavod, Beograd.

Krklec, K., Ljubenkov I. \& Bensa, A., 2011: Prirodni resursi otoka Korčule [The natural resources of the island of Korčula]. Geoadria 16(1), 3-25.

Martinović, J., 1986: Tla sekcija Korčula 1 i 2 i Sušac 2 s pedološkom kartom 1:50.000 [The soils of the section of Korčula 1 and 2 and Sušac 2 with pedological map 1:50.000]. Projektni savjet za izradu Pedološke karte SR Hrvatske, Zagreb, 1-36.

McCune, B. \& Mefford, M. J., 2006: PC-ORD: multivariate analysis of ecological data. Version 5.14. MjM software design. Gleneden Beach, Oregon.

Milović, M., 2015: Corydalis acaulis (Wulfen) Pers. In: Endemi u hrvatskoj flori. Nikolić, T., Milović, M., Bogdanović, S. \& Jasprica, N. (eds.), 193-197. Alfa d.d. Zagreb.

Nikolıć, T., 2006: Flora: priručnik za inventarizaciju i praćenje stanja [Flora: Handbook for inventory and monitoring]. Državni zavod za zaštitu prirode, Zagreb.

Nikolić, T. (ed.), 2015: Flora Croatica baza podataka [Flora Croatica database] (online). Available: http:// hirc.botanic.hr/fcd. Botanički zavod, Prirodoslovno-matematički fakultet, Sveučilište u Zagrebu. [Accessed July 6, 2015].

Nikolić, T., Bukovec, D., Šopf, J. \& Jelaska, S. D., 1998: Kartiranje flore Hrvatske - mogućnosti i standardi [The mapping of Croatian flora - opportunities and standards]. Nat. Croat. 7(1), 1-62.

Nikolić, T. \& Topić, J. (eds.), 2005: Crvena knjiga vaskularne flore Hrvatske [Red Book of Vascular Flora of Croatia]. Ministarstvo kulture. Državni zavod za zaštitu prirode. Republika Hrvatska. Zagreb.

Nikolić, T., Mitić, B. \& Boršıć, I., 2014: Flora Hrvatske Invazivne biljke [Flora of Croatia Invasive plants]. Alfa d.d., Zagreb.

PAndžA, M., Franjić, J. \& ŠKvorc, Ž., 2005: Weed and ruderal vegetation (Stellarietea mediae R. Tx. et al. ex von Rochow 1951) in central part of the east Adriatic coast. Period. biol. 107(3), 361-372. 
Pignatti, S. 1982: Flora d'Italia [Flora of Italy]. 1-3. Bologna: Edagricole.

Rivas-Martínez, S., Penas, A. \& Díaz, T.E., 2004: Biogeographic Map of Europe. Cartographic Service, Bioclimates, Thermoclimatic Belts. University of León, Spain. http://www.globalbioclimatics.org/ form/maps.htm [Accessed July 10, 2015].

Rooney, T.P., 2001: Deer impacts on forest ecosystems: a North American perspective. Forestry 74, 201208.

SHIPLEY, L.A., 1999: Grazers and browsers: How digestive morphology affects diet selection. In: Grazing Behavior of Livestock and Wildlife. Launchbaugh, K.L., Sanders, K.D. \& Mosley J.C. (eds.). Idaho Forest, Wildlife \& Range Experiment Station Bulletin 70, University of Idaho, Moscow, ID, 20-26.

ŠEgOTA, T. \& Filipčić, A., 2003: Köppenova podjela klima i hrvatsko nazivlje [Köppen classification of climates and Croatian terminology]. Geoadria 8(1), 17-37.

Trinajstić, I., 1973: As. Agropyretum mediterraneum (Kuehnh.) Br.-Bl. 1933 u vegetaciji južnodalmatinskog otoka Korčule [The Agropyretum mediterraneum (Kuehnh.) Br.-Bl. 1933 association on the south-Dalmatian island of Korčula]. Glasnik Republičkog zavoda za zaštitu prirode, Prirodnjački muzej Titograd 6, 71-76.

TRinAjSTIĆ, I. (ed.), 1975-1986: Analitička flora Jugoslavije 2(1-4) [Analytical flora of Yugoslavia 2(1-4)]. Institut za botaniku Sveučilišta u Zagrebu. Zagreb.

Trinajstić, I., 1979: Prilog poznavanju ruderalne vegetacije Hrvatskog primorja [Contribution to the knowledge of the ruderal vegetation of Hrvatsko primorje]. Fragm. Herb. Jugosl. 7, 63-67.

TrinajSTIĆ, I., 1985: Flora otočne skupine Korčule [Flora of the island of Korčula and its neighbouring islets]. Acta Bot. Croat. 44, 107-130.

Trinajstić, I., 1986: Šume dalmatinskog crnog bora - Pinus nigra Arnold subsp. dalmatica (Vis.) Franco sredozemnog područja Hrvatske [The Dalmatian black pine forests - Pinus nigra Arnold subsp. dalmatica (Vis.) Franco within the Mediterranean zone of Croatia]. Poljoprivreda i Sumarstvo (Titograd) $32,37-48$.

TRINAJSTIĆ, I., 1995: Biljni svijet otoka Korčule - pregled flore [Flora of the island of Korčula - a review]. Blatski ljetopis, 155-174.

TrinAJSTić, I., 2000: Biljni svijet otoka Korčule 2 - novi prilozi flori [Flora of the island of Korčula 2 - a new contribution]. Blatski ljetopis, 35-39.

TrinajSTIĆ, I., 2008: Biljne zajednice Republike Hrvatske [Plant communities of Croatia]. Akademija šumarskih znanosti, Zagreb, $179 \mathrm{pp}$.

Trinajstić, I. \& Kamenjarin, J., 1998: Pregled šumske vegetacije planine Kozjak [Survey of the Mt Kozjak forest vegetation]. In: Zbornik simpozija: Kaštela kolijevka Hrvatske. Hodžıć, M. (ed.), Matica hrvatska Kaštela. 504-513. 35.

Trinajstić, I. \& Kamenjarin, J., 2001: Fitocenološke značajke šuma alepskog bora as. Pistacio-Pinetum halepensis De Marco, Veri et Caneva u Hrvatskoj [Phytosociology of the Aleppo pine wood of the Pistacio-Pinetum halepensis De Marco, Veri et Caneva association in Croatia]. Sumarski institut Jastrebarsko, Radovi 36(1), 5-14.

Tutin, T.G., Burges, N.A., Chater, A.O., Edmondson, J.R.E., Heywood, V.H., Moore, D.M., Valentine, D.H., Walters, S.M. \& WebB, D.A. (eds.), 1993: Flora Europaea 1 ( $2^{\text {nd }}$ ed.), Cambridge University Press. Cambridge.

Tutin, T.G., Heywood, V H., Burges, N.A., Moore, D.M., Valentine, D.H., Walters, S.M. \& Webb, D.A. (eds.), 1968-1980: Flora Europaea 2-5. Cambridge University Press. Cambridge.

VAN DER MAAREL, E., 1979: Transformation of cover-abundance values in phytosociology and its effects on community similarity. Vegetatio $39,97-114$.

VISIANI, R. DE, 1842: Flora Dalmatica, (sive enumeratio stirpium vascularium quas hactenus in Dalmatia lectas et sibi observatas). Lipsiae, 1(3-12), 1-252.

VISIANI, R. DE, 1847: Flora Dalmatica, (sive enumeratio stirpium vascularium quas hactenus in Dalmatia lectas et sibi observatas). Apud Fridericum Hofmeister, Lipsiae, 2(3-10), 1-268.

VISIANI, R. DE, 1852: Flora Dalmatica, (sive enumeratio stirpium vascularium quas hactenus in Dalmatia lectas et sibi observatas). Apud Fridericum Hofmeister, Lipsiae, 3, 1-390.

VISIANI, R. DE, 1872-1881: Supplementum Florae Dalmaticae. 1-2. Venetiae.

Vojınović, M. \& Mıočı́, D., 1994: Istraživanje jelena lopatara na otoku Badiji [The investigation of the fallow deer on the islet of Badija]. Šum. list 117(11-12), 357-363.

VUKELIĆ, J., 2012: Šumska vegetacija Hrvatske [Forest vegetation in Croatia]. Zagreb: Šumarski fakultet, Državni zavod za zaštitu prirode. 


\section{APPENDIX 1}

\section{Locality and date of relevés}

Table 1. Limonietum anfracti typicum: Rel. 1. $X=5677164 \mathrm{Y}=4758503,17.5 .2015 ;$ Rel. $2 . \mathrm{X}=5677297$ $Y=4758584$, 17.5.2015, Rel. 3. $X=5677348$ Y=4758702, 17.5.2015, Rel. 4. $X=5677025 Y=4759295$, 17.5.2015, Rel. 5. $X=5676243$ Y=4759348, 17.5.2015, Rel. 6. $X=5676106$ Y=47588665, 17.5.2015, Rel. 7. $X=5677248 Y=4758534,4.7 .2015$. Table 2. Querco ilicis-Pinetum halepensis: Rel. 1 . $X=5677062$ $\mathrm{Y}=4758577,21.3 .2015$; Rel. 2. $\mathrm{X}=5676981 \mathrm{Y}=4758710,21.3 .2015$; Rel. $3 .=5676706 \mathrm{Y}=4758825$, 21.3.2015; Rel. 4. $X=5677408$ Y=4758946, 17.5.2015; Pistacio lentisci-Pinetum halepensis: Rel. 5. $X=5676722$ Y=4758865, 21.3.2015; Rel. 6. $X=5676762$ Y=4758876, 21.3.2015; Rel. $7 . X=5677226$ $Y=4758577,20.12 .2014 ;$ Rel. 8. $X=5677232 \mathrm{Y}=4758718,17.5 .2015 ;$ Myrto communis-Quercetum ilicis: Rel. 9. $X=5676608 \mathrm{Y}=4759022$, 21.3.2015; Rel. 10. $X=5676338 \mathrm{Y}=4758762$, 21.3.2015; Rel. 11. $X=5676260$ Y=4759127, 21.3.2015; Rel. 12. $X=5676300 Y=4758673$, 21.3.2015; Rel. 13. $X=5677111$ $Y=4758701,21.3 .2015 ;$ Rel. 14. $X=5677118$ Y=4759219, 17.5.2015; Rel. 15. $X=5676593$ Y=4759293, 17.5.2015; Rel. 16. $X=5677106$ Y=4758812, 4.7.2015; Rel. 17. $X=5677035$ Y=4758858, 4.7.2015; Rel. 18. $X=5677042 Y=4758907,4.7 .2015$; Rel. 19. $X=5677097 Y=4758745,4.7 .2015$; Rel. 20. $X=5676248$ $Y=4758870$, 4.7.2015; Rel. 21. X=5677059 Y=4758862, 4.7.2015; Myrto communis-Pistacietum lentisci: Rel. 22. $X=5677340 \mathrm{Y}=4758714$, 17.5.2015; Rel. 23. $X=5677240 \mathrm{Y}=4758552$, 4.7.2015. Table 3. Garrigue with Cistus monspeliensis: Rel. 1. $X=5676204$ Y=4759033, 4.7.2015; Rel. 2. $X=5676214$ $\mathrm{Y}=4759068$, 4.7.2015; Rel. 3. $\mathrm{X}=5676230 \mathrm{Y}=4759060$, 4.7.2015; Rel. 4. $\mathrm{X}=5676868 \mathrm{Y}=4758741$; 4.7.2015. Table 4. Parietarion judaicae: Rel. 1. $X=5676914 \mathrm{Y}=4758709,21.3 .2015$; Rel. 2 . $X=5676660$ $\mathrm{Y}=4759048$, 21.3.2015; Rel. 3. $\mathrm{X}=5676764 \mathrm{Y}=4758634,17.5 .2015$. Table 5. Centaureo cuspidataePortenschlagiellion ramosissimae: Rel. 1. $X=5676671$ Y=4759043, 21.3.2015; Rel. 2. $X=5677059$ $Y=4758862$, 4.7.2015. Table 6. Teucrio capitati-Marrubietum incani: Rel. 1 . $X=5676200$ Y=4759016; 21.3.2015; Rel. 2. X=5676200 Y=4759016; 21.3.2015; Rel. 3. X=5676968 Y=4758607; 21.3.2015; *Rel. 4. $X=5676209 Y=4759004 ; 17.5 .2015$ ( ${ }^{*}$ holotypus); Rel. 5. $X=5676229$ Y=4759004; 17.5.2015; Rel. 6. $X=5676217$ Y=4759045; 17.5.2015; Rel. 7. $X=5676245$ Y=4759007; 17.5.2015; Rel. 8. $X=5676207$ $\mathrm{Y}=4759087 ;$ 17.5.2015; Rels. 9-13. $\mathrm{X}=5676764 \mathrm{Y}=4758634$, 17.5.2015. 
Tab. 1. Limonietum anfracti typicum Ilijanić et S. Hećimović 1982.

\begin{tabular}{|c|c|c|c|c|c|c|c|c|}
\hline No. of relevés & 1 & 2 & 3 & 4 & 5 & 6 & 7 & \\
\hline No. of taxa & 8 & 4 & 4 & 5 & 11 & 3 & 4 & $\mathrm{P}$ \\
\hline Altitude (m a.s.l.) & 0 & 0 & 0 & 1 & 1 & 0 & 0 & $\mathrm{r}$ \\
\hline Slope $\left(^{\circ}\right)$ & . & . & . & 10 & 10 & 2 & 2 & e \\
\hline Aspect & . & . & . & $\mathrm{N}$ & $\mathrm{N}$ & S & SE & s. \\
\hline Vascular plant cover (\%) & 40 & 10 & 20 & 30 & 5 & 5 & 10 & \\
\hline Plot size $\left(\mathrm{m}^{2}\right)$ & 20 & 20 & 20 & 20 & 20 & 20 & 25 & $\%$ \\
\hline \multicolumn{9}{|l|}{ Char. Ass. } \\
\hline Limonium dictyophorum & + & 3 & 4 & 4 & 1 & 1 & 1 & 100 \\
\hline \multicolumn{9}{|l|}{ Crithmo maritimi-Staticetea } \\
\hline Euphorbia pinea & + & + & + & + & + & + & . & 86 \\
\hline Crithmum maritimum & . & . & + & . & + & . & + & 43 \\
\hline Senecio bicolor ssp. cineraria & 3 & . & . & . & . & . & . & 14 \\
\hline Vincetoxicum hirundinaria ssp. adriaticum & . & . & . & + & . & . & . & 14 \\
\hline Silene vulgaris ssp. angustifolia & . & . & . & . & + & . & . & 14 \\
\hline Inula crithmoides & . & . & . & . & . & + & . & 14 \\
\hline
\end{tabular}

\section{Companions}

Asplenietea trichomanis

\begin{tabular}{|l|c|c|c|c|c|c|c|c|}
\hline Inula verbascifolia & + & 1 & 1 & 1 & + & $\cdot$ &. & 71 \\
\hline Capparis orientalis & $\cdot$ & $\cdot$ & $\cdot$ & $\cdot$ & + & $\cdot$ & + & 29 \\
\hline
\end{tabular}

Nerio oleandri-Tamaricetea africanae

\begin{tabular}{|l|l|l|l|l|l|l|l|l|}
\hline Vitex agnus-castus & 1 & $\cdot$ & $\cdot$ & $\cdot$ & $\cdot$ & $\cdot$ & + & 29
\end{tabular}

Artemisietea vulgaris

Dittricia viscosa

\section{Stellarietea mediae}

\begin{tabular}{|l|c|c|c|c|c|c|c|c|}
\hline Delphinium staphisagria & 3 & $\cdot$ & $\cdot$ & $\cdot$ & $\cdot$ & $\cdot$ & $\cdot$ & 14 \\
\hline Chenopodium album & + & $\cdot$ & $\cdot$ & $\cdot$ & $\cdot$ & $\cdot$ & $\cdot$ & 14 \\
\hline Quercetea
\end{tabular}

Quercetea ilicis

Arum italicum

\begin{tabular}{|l|l|l|l|l|l|l|l}
+ & $\cdot$ & $\cdot$ & $\cdot$ & $\cdot$ & $\cdot$ & $\cdot$ & 14 \\
\hline
\end{tabular}

\section{Thero-Brachypodietea ramosi}

Brachypodium retusum

Reichardia picroides

Valantia muralis

Allium subhirsutum

\section{Ammophiletea}

Elymus pycnanthus

\begin{tabular}{|c|c|c|c|}
\hline+ & $\cdot$ & $\cdot$ & 14 \\
\hline+ & $\cdot$ & $\cdot$ & 14 \\
\hline+ & $\cdot$ & $\cdot$ & 14 \\
\hline 1 & $\cdot$ & $\cdot$ & 14 \\
\hline
\end{tabular}




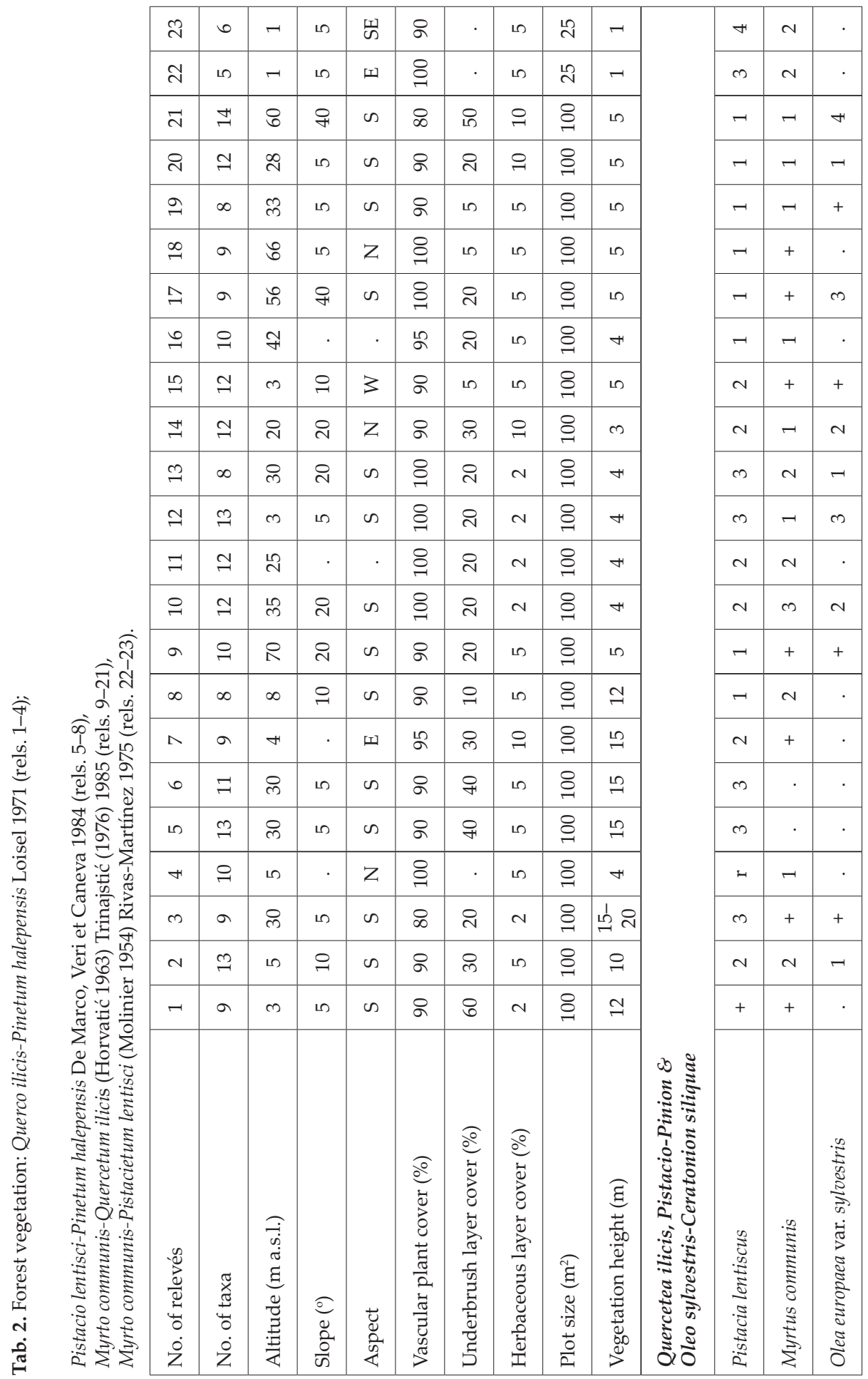




\begin{tabular}{|c|c|c|c|c|c|c|c|c|c|c|c|c|c|c|c|c|c|c|c|}
\hline+ & . & . & & & . & . & 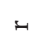 & $\cdot$ & $\cdot$ & $\cdot$ & . & . & . & $\cdot$ & . & $\cdot$ & . & . & . \\
\hline+ & . & . & & & $\cdot$ & . & . & . & . & . & . & . & . & . & 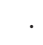 & . & . & . & . \\
\hline • & $r$ & $\cdot$ & + & & - & + & & $\infty$ & + & + & & . & - & & & & . & + & . \\
\hline . & $\cdot$ & . & & & $H$ & + & $r$ & + & + & $r$ & 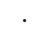 & - & . & . & . & . & . & + & . \\
\hline . & . & . & & & $H$ & + & + & $N$ & + & . & . & . & . & . & . & . & . & . & . \\
\hline . & + & + & & & 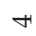 & + & - & $\infty$ & + & . & . & . & . & . & . & . & . & . & . \\
\hline . & + & . & & & - & + & . & + & + & . & . & . & . & . & & . & . & $H$ & . \\
\hline$H$ & . & . & & & 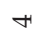 & $r$ & $r$ & $N$ & + & + & . & . & $H$ & . & . & . & . & . & . \\
\hline . & . & . & & & 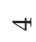 & $N$ & - & + & . & $N$ & . & - & $N$ & + & . & . & . & . & . \\
\hline . & . & . & & & 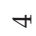 & $m$ & $m$ & $r$ & . & - & . & . & . & + & . & + & . & . & . \\
\hline . & . & . & & & t & + & - & $\infty$ & . & - & . & . & . & . & . & . & $\cdot$ & . & . \\
\hline . & . & . & & & $N$ & + & $\neg$ & $N$ & - & + & + & + & + & + & . & . & . & . & . \\
\hline . & . & . & & & $\infty$ & + & - & + & + & + & + & + & + & + & . & . & . & . & . \\
\hline . & . & . & & & 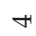 & + & $r$ & - & - & $r$ & . & + & + & . & . & + & . & . & . \\
\hline . & . & . & & & 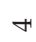 & + & - & $N$ & . & . & + & . & . & + & + & . & . & . & . \\
\hline 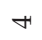 & . & . & & & + & + & + & + & . & . & . & . & . & . & . & + & . & . & . \\
\hline 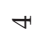 & . & . & & & - & . & - & + & + & . & + & . & . & . & . & . & . & . & . \\
\hline$\infty$ & . & . & & & + & + & $r$ & + & . & . & + & . & . & + & + & . & . & . & + \\
\hline+ & . & . & & & - & + & + & . & . & . & + & . & . & + & + & . & . & . & . \\
\hline$n$ & . & . & & & $N$ & . & $N$ & . & + & $\infty$ & . & . & + & $H$ & . & . & . & . & . \\
\hline 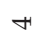 & . & . & & & $\infty$ & + & + & . & . & . & + & . & . & . & + & . & . & . & . \\
\hline$m$ & . & . & & & $N$ & + & - & - & - & . & + & + & . & . & + & . & + & . & . \\
\hline 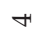 & . & . & & & $m$ & . & + & . & . & . & $N$ & . & . & + & - & . & + & . & . \\
\hline 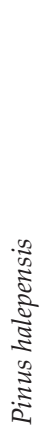 & 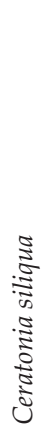 & 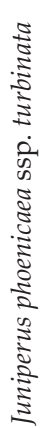 & 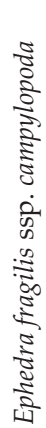 & 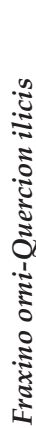 & 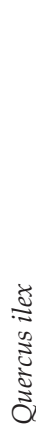 & 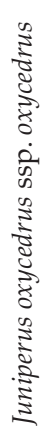 & 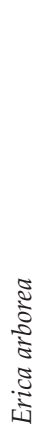 & 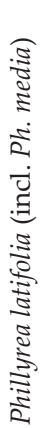 & 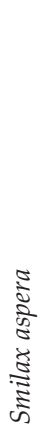 & 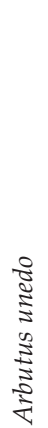 & 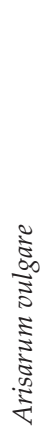 & 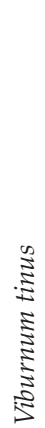 & 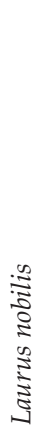 & 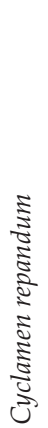 & 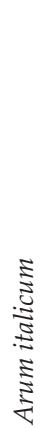 & 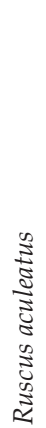 & 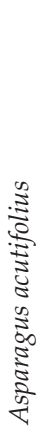 & 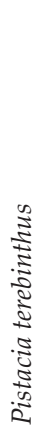 & 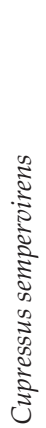 \\
\hline
\end{tabular}




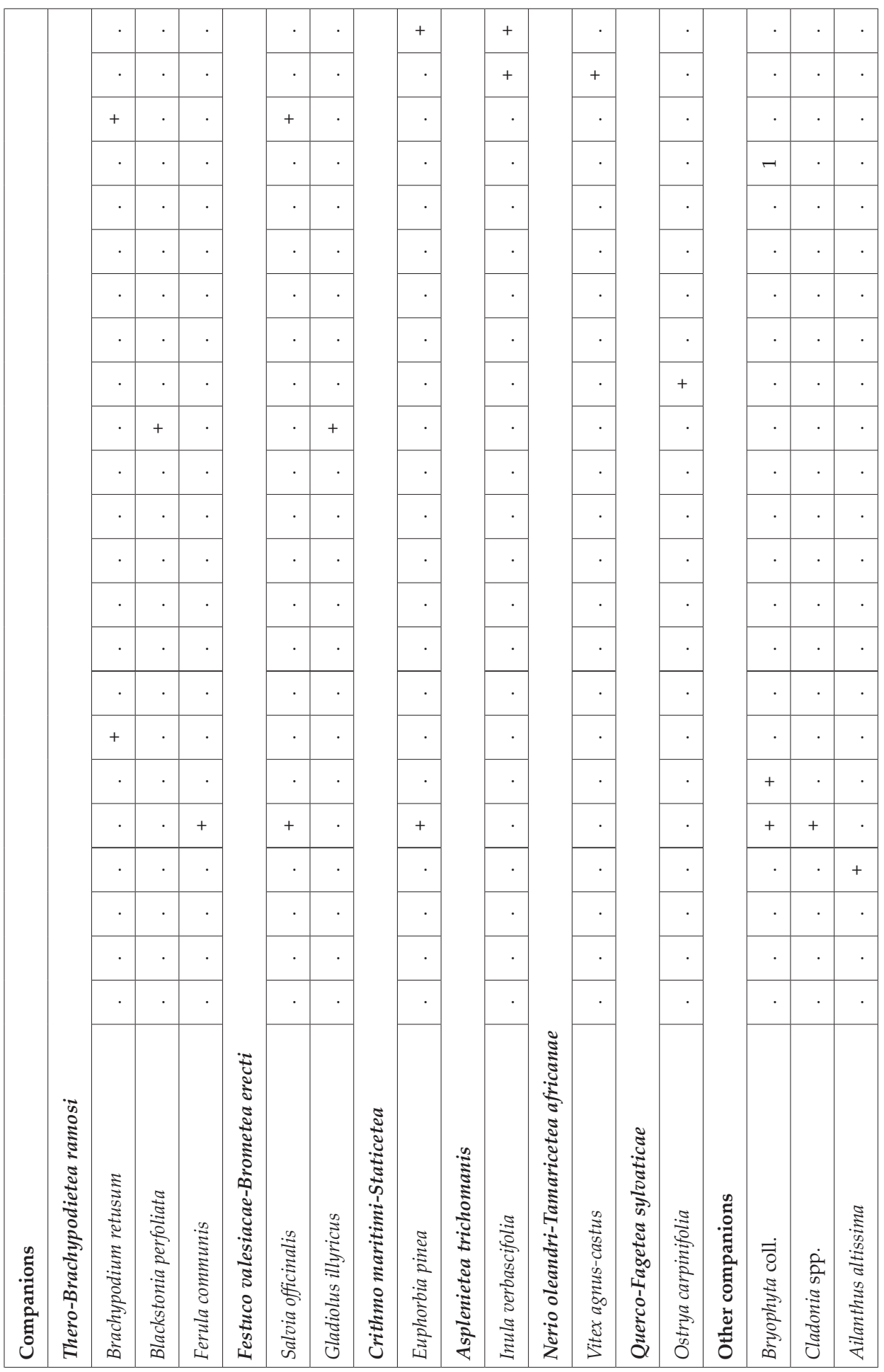


Tab. 3. Garrigue with Cistus monspeliensis.

\begin{tabular}{|c|c|c|c|c|c|}
\hline No. of relevés & 1 & 2 & 3 & 4 & \\
\hline No. of taxa & 6 & 6 & 2 & 10 & \\
\hline Altitude (m a.s.l.) & 30 & 30 & 30 & 2 & $\mathrm{P}$ \\
\hline Slope $\left(^{\circ}\right)$ & . & . & . & 5 & $\mathrm{r}$ \\
\hline Aspect & . & . & . & $\mathrm{S}$ & e \\
\hline Vascular plant cover $(\%)$ & 40 & 80 & 90 & 80 & s. \\
\hline Plot size $\left(\mathrm{m}^{2}\right)$ & 25 & 25 & 25 & 25 & \\
\hline \multicolumn{6}{|l|}{ Cisto-Micromerietea } \\
\hline Cistus monspeliensis & 3 & 4 & 5 & 4 & 4 \\
\hline \multicolumn{6}{|l|}{ Companions } \\
\hline \multicolumn{6}{|l|}{ Thero-Brachypodietea ramosi } \\
\hline Teucrium capitatum & 1 & 1 & + & + & 4 \\
\hline \multicolumn{6}{|l|}{ Artemisietea vulgaris } \\
\hline Dittrichia viscosa & + & + & . & + & 3 \\
\hline \multicolumn{6}{|l|}{ Quercetea ilicis } \\
\hline Pistacia lentiscus & . & 1 & . & 2 & 2 \\
\hline Juniperus oxycedrus ssp. oxycedrus & + & . & . & . & 1 \\
\hline Myrtus communis & . & . & . & + & 1 \\
\hline \multicolumn{6}{|l|}{ Stellarietea mediae } \\
\hline Delphinium staphisagria & 1 & + & . & 1 & 3 \\
\hline Marrubium incanum & . & . & . & + & 1 \\
\hline Ruta graveolens & . & . & . & + & 1 \\
\hline \multicolumn{6}{|l|}{ Crithmo maritimi-Staticetea } \\
\hline Euphorbia pinea & + & . & . & 1 & 2 \\
\hline \multicolumn{6}{|l|}{ Other companions } \\
\hline Ailanthus altissima & . & + & . & . & 1 \\
\hline Melia azedarach & . & . & . & 1 & 1 \\
\hline
\end{tabular}


Tab. 4. Parietarion judaicae Segal 1969.

\begin{tabular}{|c|c|c|c|c|}
\hline No. of relevés & 1 & 2 & 3 & \\
\hline No. of taxa & 6 & 4 & 2 & $\mathrm{P}$ \\
\hline Altitude (m a.s.l.) & 3 & 70 & 1 & $\mathrm{r}$ \\
\hline Slope $\left(^{\circ}\right)$ & 90 & 90 & 90 & $\mathrm{e}$ \\
\hline Aspect & $\mathrm{N}$ & $\mathrm{E}$ & $\mathrm{E}$ & s. \\
\hline Vascular plant cover (\%) & 20 & 20 & 10 & \\
\hline Plot size $\left(\mathrm{m}^{2}\right)$ & 10 & 2 & 4 & \\
\hline \multicolumn{5}{|l|}{$\begin{array}{l}\text { Parietarietea judaicae } \\
\text { and lower syntaxa }\end{array}$} \\
\hline Asplenium ceterach & 2 & 1 & . & 2 \\
\hline Parietaria judaica & 1 & . & . & 1 \\
\hline Veronica cymbalaria & . & + & . & 1 \\
\hline Theligonum cynocrambe & + & . & . & 1 \\
\hline \multicolumn{5}{|l|}{ Companions } \\
\hline \multicolumn{5}{|l|}{ Artemisietea vulgaris } \\
\hline Conyza canadensis & + & . & . & 1 \\
\hline \multicolumn{5}{|l|}{ Asplenietea trichomanis } \\
\hline Capparis orientalis & + & . & . & 1 \\
\hline \multicolumn{5}{|l|}{ Tuberarietea guttatae } \\
\hline Geranium rontudifolium & . & + & . & 1 \\
\hline \multicolumn{5}{|c|}{ Crithmo maritimi-Staticetea } \\
\hline Euphorbia pinea & . & . & + & 1 \\
\hline \multicolumn{5}{|l|}{ Asplenietea trichomanis } \\
\hline Corydalis acaulis & . & . & 1 & 1 \\
\hline \multicolumn{5}{|l|}{ Other companion } \\
\hline Bryophyta coll. & + & + & . & 2 \\
\hline
\end{tabular}


Tab. 5. Centaureo cuspidatae-Portenschlagiellion ramosissimae Trinajstić 1980.

\begin{tabular}{|c|c|c|c|}
\hline No. of relevés & 1 & 2 & \\
\hline No. of taxa & 7 & 17 & $\mathrm{P}$ \\
\hline Altitude (m a.s.l.) & 70 & 65 & $\mathrm{r}$ \\
\hline Slope $\left(^{\circ}\right)$ & 90 & 90 & e \\
\hline Aspect & S & $\mathrm{S}$ & s. \\
\hline Vascular plant cover $(\%)$ & 10 & 30 & \\
\hline Plot size $\left(\mathrm{m}^{2}\right)$ & 6 & 20 & \\
\hline \multicolumn{4}{|l|}{ Asplenietea trichomanis } \\
\hline Campanula pyramidalis & 1 & 1 & 2 \\
\hline Inula verbascifolia & + & 1 & 2 \\
\hline \multicolumn{4}{|l|}{ Companions } \\
\hline \multicolumn{4}{|l|}{ Quercetea ilicis } \\
\hline Cyclamen repandum & + & . & 1 \\
\hline Prasium majus & + & . & 1 \\
\hline Ephedra fragilis ssp. campylopoda & . & 1 & 1 \\
\hline Asparagus acutifolius & . & + & 1 \\
\hline Colutea arborescens & + & . & 1 \\
\hline \multicolumn{4}{|l|}{ Thero-Brachypodietea ramosi } \\
\hline Teucrium capitatum & . & + & 1 \\
\hline Brachypodium retusum & . & + & 1 \\
\hline Sideritis romana & . & + & 1 \\
\hline Convolvulus althaeoides ssp. tenuissimus & . & + & 1 \\
\hline Allium subhirsutum & . & 1 & 1 \\
\hline \multicolumn{4}{|l|}{ Stellarietea mediae } \\
\hline Mercurialis annua & + & . & 1 \\
\hline Fumaria capreolata & + & . & 1 \\
\hline \multicolumn{4}{|l|}{ Festuco valesiacae-Brometea erecti } \\
\hline Salvia officinalis & . & + & 1 \\
\hline Muscari comosum & . & + & 1 \\
\hline Teucrium chamaedrys & . & + & 1 \\
\hline Bituminaria bituminosa & . & + & 1 \\
\hline Aethionema saxatile & . & + & 1 \\
\hline \multicolumn{4}{|l|}{ Querco-Fagetea sylvaticae } \\
\hline Coronilla emerus ssp. emeroides & . & + & 1 \\
\hline \multicolumn{4}{|l|}{ Other companions } \\
\hline Galium sp. & . & + & 1 \\
\hline Orobanche sp. & . & + & 1 \\
\hline
\end{tabular}


Tab 6. Teucrio capitati-Marrubietum incani Jasprica et Milović 2016, ass. nova hoc loco

\begin{tabular}{|c|c|c|c|c|c|c|c|c|c|c|c|c|c|c|}
\hline No. of relevés & 1 & 2 & 3 & $4^{*}$ & 5 & 6 & 7 & 8 & 9 & 10 & 11 & 12 & 13 & \\
\hline No. of taxa & 12 & 20 & 19 & 10 & 5 & 10 & 11 & 11 & 10 & 8 & 8 & 8 & 12 & $\mathrm{P}$ \\
\hline Altitude (m a.s.1.) & 20 & 20 & 2 & 20 & 20 & 20 & 20 & 20 & 1 & 1 & 1 & 2 & 2 & $\mathrm{r}$ \\
\hline Slope $\left({ }^{\circ}\right)$ & . & . & 5 & . & . & . & . & . & $1-2$ & $1-2$ & $1-2$ & $1-2$ & $1-2$ & $\mathrm{e}$ \\
\hline Aspect & . & . & $S$ & . & . & . & . & . & S & S & S & S & S & s. \\
\hline Vascular plant cover (\%) & 70 & 90 & 20 & 60 & 40 & 30 & 30 & 30 & 70 & 70 & 70 & 40 & 80 & \\
\hline Plot size $\left(\mathrm{m}^{2}\right)$ & 50 & 50 & 50 & 25 & 25 & 25 & 25 & 25 & 25 & 20 & 20 & 20 & 20 & $\%$ \\
\hline \multicolumn{15}{|l|}{ Char. Ass. } \\
\hline Marrubium incanum & 2 & 1 & 1 & 4 & 3 & 4 & 4 & 2 & 4 & 2 & 2 & 1 & + & 100 \\
\hline Delphinium staphisagria & + & 1 & + & + & . & + & . & + & + & 2 & + & + & + & 87 \\
\hline
\end{tabular}

Stellarietea mediae and lower syntaxa

\begin{tabular}{|c|c|c|c|c|c|c|c|c|c|c|c|c|c|c|}
\hline Ruta graveolens & . & + & . & . & + & 1 & + & . & . & + & . & + & . & 46 \\
\hline Euphorbia peplus & 1 & + & + & + & . & . & . & . & . & + & . & . & . & 38 \\
\hline Aphanes arvensis & + & $\mathrm{r}$ & . & + & . & . & . & . & . & . & . & . & . & 23 \\
\hline Heliotropium europaeum & . & . & . & . & . & . & . & . & 2 & . & + & + & . & 23 \\
\hline Euphorbia helioscopia & + & . & . & . & . & . & . & . & . & + & . & . & . & 15 \\
\hline Cynodon dactylon & . & . & . & . & . & . & . & . & . & + & + & . & . & 15 \\
\hline Fumaria capreolata & . & . & . & . & . & $\cdot$ & . & . & . & . & . & + & + & 15 \\
\hline Silene vulgaris & . & . & . & . & . & . & . & . & . & . & . & + & + & 15 \\
\hline Scrophularia peregrina & $\cdot$ & . & . & + & . & . & . & . & . & $\cdot$ & $\cdot$ & . & + & 15 \\
\hline Convolvulus arvensis & . & + & . & . & . & $\cdot$ & . & $\cdot$ & . & . & . & . & . & 8 \\
\hline Chenopodium murale & $\cdot$ & . & . & + & . & $\cdot$ & . & $\cdot$ & . & . & . & . & . & 8 \\
\hline Papaver rhoeas & . & . & . & . & . & $\cdot$ & . & + & . & . & . & . & . & 8 \\
\hline Malva sylvestris & . & . & . & . & . & . & . & . & . & . & . & . & + & 8 \\
\hline
\end{tabular}

\section{Thero-Brachypodietea ramosi}

\begin{tabular}{|c|c|c|c|c|c|c|c|c|c|c|c|c|c|c|}
\hline Teucrium capitatum & 2 & 1 & 1 & 2 & 1 & 1 & + & 3 & 2 & 2 & 2 & 1 & 3 & 100 \\
\hline Ferula communis & + & 5 & 2 & . & + & 1 & + & + & $\cdot$ & . & . & - & + & 62 \\
\hline $\begin{array}{l}\text { Centaurium erythraea ssp. } \\
\text { erythraea }\end{array}$ & $\cdot$ & + & . & . & . & . & · & . & $\cdot$ & $\cdot$ & $\cdot$ & $\cdot$ & . & 8 \\
\hline Sideritis romana & $\cdot$ & + & . & . & . & . & . & . & . & . & . & . & . & 8 \\
\hline
\end{tabular}

\section{Crithmo maritimi-Staticetea}

Euphorbia pinea

Senecio bicolor ssp. cineraria

\begin{tabular}{|l|l|l|l|l|l|l|l|l|l|l|l|l|l|}
+ & + & 1 & + & + & $\cdot$ & + & + & 1 & $\cdot$ & + & + & + & 85 \\
\hline$\cdot$ & $\cdot$ & $\cdot$ & $\cdot$ & $\cdot$ & $\cdot$ & $\cdot$ & $\cdot$ & + & $\cdot$ & + & $\cdot$ & + & 23 \\
\hline
\end{tabular}

\section{Quercetea ilicis}




\begin{tabular}{|c|c|c|c|c|c|c|c|c|c|c|c|c|c|c|}
\hline Pistacia lentiscus & + & + & + & . & . & + & + & + & + & . & . & . & + & 62 \\
\hline Arum italicum & + & 3 & 1 & . & . & + & + & + & $\cdot$ & . & . & . & . & 46 \\
\hline Myrtus communis & . & + & + & . & . & . & . & . & & . & . & . & . & 15 \\
\hline $\begin{array}{l}\text { Juniperus oxycedrus ssp. } \\
\text { oxycedrus }\end{array}$ & . & + & $\cdot$ & . & . & . & . & . & $\cdot$ & . & . & . & . & 8 \\
\hline Olea europaea var. sylvestris & . & . & + & . & . & . & . & . & . & . & . & . & . & 8 \\
\hline Arisarum vulgare & . & . & + & . & . & . & . & . & & . & . & . & . & 8 \\
\hline \multicolumn{15}{|l|}{ Artemisietea vulgaris } \\
\hline Dittrichia viscosa & + & . & . & 1 & . & + & + & + & . & . & . & . & . & 38 \\
\hline Ailanthus altissima & . & . & . & . & . & + & . & + & + & . & . & . & + & 31 \\
\hline Sonchus oleraceus & . & . & + & . & . & . & . & . & . & . & . & . & . & 8 \\
\hline Conyza canadensis & . & . & + & . & . & . & . & . & . & . & . & . & . & 8 \\
\hline \multicolumn{15}{|l|}{ Rosmarinetea officinalis } \\
\hline Cistus monspeliensis & + & 1 & . & . & . & + & + & 1 & . & . & . & . & . & 38 \\
\hline \multicolumn{15}{|c|}{ Nerio oleandri-Tamaricetea africanae } \\
\hline Vitex agnus-castus & . & . & . & + & . & . & + & . & + & . & . & . & . & 23 \\
\hline \multicolumn{15}{|c|}{ Festuco valesiacae-Brometea erecti } \\
\hline Hypericum perforatum & . & . & . & . & . & . & + & . & + & . & . & . & . & 15 \\
\hline Colchicum hungaricum & . & + & . & . & . & . & . & . & . & . & . & . & . & 8 \\
\hline Muscari comosum & . & . & + & . & . & . & . & . & . & . & . & . & . & 8 \\
\hline Petrorhagia saxifraga &. & . & + & . & . & . &. & . & . & . & . & . & . & 8 \\
\hline \multicolumn{15}{|l|}{ Asplenietea trichomanis } \\
\hline Ficus carica & . & + & . & . & . & . & . & . & . & . & . & . & . & 8 \\
\hline Misopates orontium & . & . & + & . & . & . & . & . & . & . & . & . & . & 8 \\
\hline Capparis orientalis & . & . & . & . & . & . & . & . & . & + & . & . & . & 8 \\
\hline \multicolumn{15}{|l|}{ Querco-Fagetea sylvaticae } \\
\hline Tamus communis & . & + & . & . & . & . & . & . & . & . & . & . & . & 8 \\
\hline Morus alba & . & + & . & . & . & . & . & . & & . & . & . & . & 8 \\
\hline \multicolumn{15}{|l|}{ Tuberarietea guttatae } \\
\hline Galium murale & . & . & + & . & . & . & . & . & . & . & . & . & . & 8 \\
\hline Geranium rotundifolium & . & . & + & . & . & . & . & . & . & . & . & . & . & 8 \\
\hline \multicolumn{15}{|l|}{ Other companions } \\
\hline Bryophyta coll. & . & . & $\mathrm{r}$ & . & . & . & . & . & . & . & . & . & . & 8 \\
\hline Melia azedarach & . & . & . & . & . & . & . & . & . & . & + & . & . & 8 \\
\hline
\end{tabular}

